\title{
Article
}

\section{Born into care: Evidence of a failed state}

\author{
Bilson, Andrew and Bywaters, Paul
}

Available at http://clok.uclan.ac.uk/37933/

Bilson, Andrew and Bywaters, Paul (2020) Born into care: Evidence of a failed state. Child and Youth Services Review, 116.

It is advisable to refer to the publisher's version if you intend to cite from the work. http://dx.doi.org/10.1016/j.childyouth.2020.105164

For more information about UCLan's research in this area go to

http://www.uclan.ac.uk/researchgroups/ and search for < name of research Group>.

For information about Research generally at UCLan please go to http://www.uclan.ac.uk/research/

All outputs in CLoK are protected by Intellectual Property Rights law, including Copyright law. Copyright, IPR and Moral Rights for the works on this site are retained by the individual authors and/or other copyright owners. Terms and conditions for use of this material are defined in the policies page.

\section{CLoK}

Central Lancashire online Knowledge www.clok.uclan.ac.uk

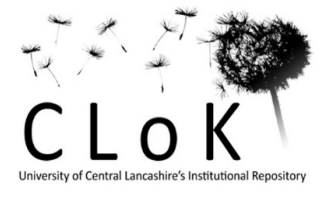




\section{Born into care: evidence of a failed state.}

\section{Abstract}

This paper shows that the number of children who entered state care in England before they are a week old was $44 \%$ higher than shown by previous research if children 'voluntarily' placed in care are included. A series of freedom of information requests show the rapid increase between 2007 and 2017. The difference in rates between local authorities is also rapidly increasing and bigger increases are associated with both levels of deprivation and local authorities whose performance was graded inadequate or needing improvement by the Office for Standards in Education. In 25 local authorities an average of one child in every 100 live births is separated from its parents in the first week in life, with very few ever being reunited. The growth in numbers and proportions of children entering care in the first week of life is a key driver of adoption rates. But far from acting as a form of prevention, with lower proportions of older children entering care, where local authorities undertake very early removal from parents the opposite is true. This points to a possible spiral of failure as a high proportion of parents who have been in care risk losing their children at birth.

\section{Introduction}

In two ground breaking recent reports, covering England and Wales respectively, the Nuffield Family Justice Observatory (NFJO, 2018; 2019) has shone light on the numbers of children removed from their mothers and placed in care through care proceedings starting in the first week of life. These children have been described as being 'born into care' (BIC). Drawing on national data from the Children and Family Court Advisory and Support Service (CAFCASS) and CAFCASS Cymru, respectively, the authors found that, in the year 2016-17, 35 babies in every 10,000 live births in England were taken into care within the first week of life - as a 'newborn'. In Wales, 83 babies per 10,000 live births were taken into care within two weeks in 2017/18. That equates to 1 baby in every 285 live births in England; in Wales to 1 in every 120 over the longer period. However, in this article we argue that these NFJO data are significant underestimates and that the profound inequalities in children's chances of being separated from their parents at birth reflect a failure of the state to meet its obligations under the Convention of the Rights of the Child.

The NFJO studies report that in both England and Wales the incidence of removal at birth has been rapidly rising. The proportion of live births subject to care proceedings in England increased by $135 \%$ between 2008 and 2016/17; in Wales it had almost doubled since 2011. The first week of life involve by far the greatest risk to a child of entry to care of any period in childhood. The rate in Wales was reported to be much higher than in England. By the time babies were four weeks old, I in 118 Welsh children had been subject to care proceedings compared to 1 in 208 English children.

In addition, the NFJO authors found considerable variation between local authorities and between regions in the proportion of children being removed at birth. In several local authorities in England around 1 child in 100 was BIC (in the most extreme case it was 1 in 55), while in others the rate was less than 1 in 1000 live births. 
For a child to meet the legal requirements for a care order, a 'court must have 'reasonable grounds' to believe that the child has suffered or is at risk of suffering significant harm and that this is as a result of care provided by parents falling below a reasonable standard' (NFJO 2019, 12). In fact, less than half of all children removed at birth had an older sibling who had been removed through a court order. The majority (53\% in England, $51 \%$ in Wales) were assessed as being at risk without the parents having been previously found by a court not to have provided good enough care for a child.

The outcome was adoption for around half of all children BIC with fewer than 1 in 5 returning home. Little is known about the quality of practice with the birth families of children BIC but earlier studies (Broadhurst et al., 2015, p.16; 2017) reported 'a policy lacuna regarding post-removal support to parents' who had had a child removed. A number of local authorities have been attempting to offer better services to such parents in order to prevent repeat removals (Bellew and Peeran, 2017; Cox et al, 2015).

These reports of rapidly growing, inequitably distributed, coercive, high end admissions to care, often based on prediction of future parenting rather than evidence of previous harm, with little subsequent engagement with birth parents raise considerable ethical concerns. The rise in popularity of early intervention and a presumption that adoption provides the best outcomes for children at risk of significant harm has a long history in the UK which has been reinforced in recent times by a focus on the first 1000 days or early years of a child's life (Allen, 2011; Field, 2010). However, the link between preventive early intervention and removing children from birth parents for adoption was not the declared intention of either the Field or Allen reports. When published in 2010 and 2011, these two influential reports were centrally concerned to promote the prevention of harm to children by helping families under stress and thereby aiming to "keep families together and save many children from the trauma of break-up and removal' Allen, 2011: Foreword).

The Allen Report called for substantial state investment in the early years and early intervention. However, the reverse happened under the austerity policies of the Coalition and subsequent Conservative governments: crystallised by the decimation of funding for Sure Start children's centres. Government policy pushed for taking more children into care and investing in adoption with key guidance promoting a culture of child rescue and growing authoritarian interventionism (Parton and Williams, 2017). This was reflected in many aspects of guidance and is summarised in this statement: "A desire to think the best of adults and to hope they can overcome their difficulties should not trump the need to rescue children from chaotic, neglectful and abusive homes." (HM Government, 2013 p.22). Despite the limitations of research about the relative benefits of birth and alternative families, which failed to control for the families' socio-economic circumstances, adoption came to be viewed as a gold standard of provision, with foster care as second best (Harwin et al., 2016).

Alongside these changes in policy, Brown and Ward's (2013) research summary commissioned to be used in training the judiciary also argued for decisions in "the child's timeframe" and conclude that:

Where parents do not have the capacity to overcome entrenched, adverse behaviour patterns that damage their children's welfare, placement in the care of the local authority is generally more beneficial for children than remaining at home (or returning there), and adoption is likely to lead to the best outcomes for very young children. (p. 74)

This argument for the necessity for speedy intervention has been challenged over its interpretation of research, particularly attachment theory and a contested interpretation of neuroscience (White, 
Gibson and Wastell, 2019; Wastell and White, 2012, 2017). Whilst Brown and Ward cite a number of evidence based programs for supporting families, far less traction appears to have been secured by those continuing to argue for better support for parents than those arguing for removal. Thus, the president of the family division of the high court of England and Wales, Sir Andrew McFarlane said that it is easier to initiate care proceedings than to provide complex support for families

(MacFarlane, 2018). Family court judgements have also identified failures by responsible authorities to adequately consider alternatives to the most powerful form of state intervention in family life: adoption without consent (Fenton Glynn, 2015; MacFarlane, 2017).

It is questionable whether this pattern of early removal of babies from birth parents is compatible with the UN Convention of the Rights of the Child. The most often quoted clause in the UN Convention on the Rights of the Child is that the 'best interests of the child' should be a primary consideration and this principle is central to arguments for taking care proceedings. Less commonly referred to is the statement in Article 7 that 'The child ... shall have the right from birth ... to know and be cared for by his or her parents.' Article 7 places an obligation on the state to 'ensure the implementation of these rights'. Article 18 spells out states must use 'their best efforts to ensure recognition of the principle that both parents have common responsibilities for the upbringing and development of the child. Parents or, as the case may be, legal guardians, have the primary responsibility for the upbringing and development of the child. ...' Therefore States Parties shall render appropriate assistance to parents and legal guardians in the performance of their child-rearing responsibilities and shall ensure the development of institutions, facilities and services for the care of children.' However, under austerity policies, the funding of children's social care services has been reduced against a background of growing socio-economic pressures on families resulting from harsh welfare policies, economic stagnation, increasingly precarious job and housing markets coupled with cuts in other services providing support to families. These cuts have fallen disproportionately on disadvantaged geographical areas, exacerbating social, economic and environmental inequalities between places and between people (Webb and Bywaters, 2018). This picture was underlined by the European Union Directorate General For Internal Policies in 2015, requiring the UK government to protect resources for children's services despite austerity (Fenton Glynn, 2015).

The aim of this article is to extend the valuable research reported by the NFJO and Broadhurst et al., $(2015 ; 2017)$ which has drawn attention to the scale and growth in the numbers of children BIC and the consequences for birth parents. The study used a Freedom of Information Act request to the Department for Education in England to produce new evidence about the extent to which children in the UK are being BIC. First, we consider whether and to what extent the earlier reports may have underestimated the size of the issue by focusing only on children separated from their parents through court proceedings. As the England report outlines (NFJO 2018, 9n), 'Infants can become looked after by the State through care proceedings or through s.20 of the Children Act 1989. Under s. 20 children are 'accommodated' by the State by way of parental agreement rather than court order. Although many cases involving new born babies initially agreed under 5.20 will progress to care proceedings very shortly after birth, it is likely that a focus on s.31 proceedings within 7 days of birth misses some cases' (NFJO, 2018, p.12). Second, we identify the increase in BIC rates, taking S.20 admissions into account. Third, we consider what evidence there is about the placement outcomes of entry to care in the first week of life before, fourthly, examining inequalities in children's chances of being BIC and alternative explanations. 


\section{Method}

This study uses data from statistical returns on looked after children sent by all local authorities in England to central government. Government holds a large database with information gathered annually about children entering care, leaving care and changes in their legal status and placements which has been analysed by Mcgrath-Loan et al (2018) to look at longitudinal patterns of care. The data used here was requested through Freedom of Information (Fol) requests so the researchers did not have direct access to the original data. Three Fols were used and a series of tables were produced by the Department for Education providing breakdowns on the age at entry to care, ethnicity, placement on leaving care, legal status on entry to care, and local authority responsible. This data has been combined with data already published by the Department for Education for some of the later calculations. As all data that can be accessed by freedom of information is in the public domain it does not constitute personal data and does not require ethical approval.

\subsection{Limitations}

Where between one and five children fell into a category the data was redacted. In these the mean of the possible values (three) was used to allow inclusion in analysis. This may create a very small error on analyses that combine data across local authorities but may cause a larger discrepancy where findings on some individual small authorities are reported. This applied to 14 local authorities in the data for children BIC in 2017. The ability to fully check the quality of the data is also limited, though the Department for Education does carry out checks of quality and accuracy.

\section{Key findings}

\subsection{Many more children BIC}

Including all new born babies who started being looked after in week 1 means that the number of children BIC in England was 44\% higher than the FJO found in its ten-year period. Graph 1 shows this difference. Between 2008 and 2017, 24,230 children in total were BIC compared with the FJO report's finding of 16,849 subject to care proceedings within a week of birth. As the use of S. 20 for admitting children to care rather than court orders has come under judicial scrutiny, the proportion of 'missing' cases in the NFJO report has reduced from 63\% in 2008-2011 to 35\% in the period 201517 , but remains large. In the most recent year, 2016/17, the FJO report recorded 2,447 children where proceedings started within a week of birth (2018, table 6, p. 33) whilst this study found 1,880 whose initial order was either a care order (including interim care orders) or detained for child protection and 980 who entered on voluntary agreements: 2860 in all. This suggests that a large proportion of children who entered on voluntary agreements had care proceedings initiated within a week of birth. But the key point made here is that the number of children BIC is even larger than previously reported. 
Graph 1: Number of children becoming looked after in England within 1 week of birth compared to FJO Report.

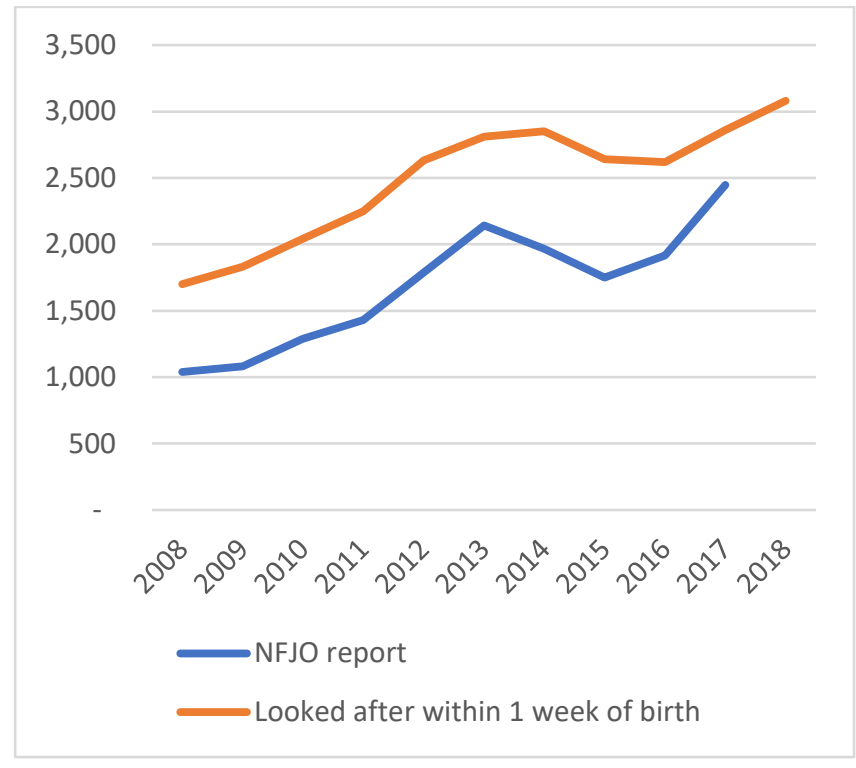

\subsection{Entries to care on care orders quadrupled}

The information from these Fol requests shows that half (49.6\%) of children initially entered care on a voluntary agreement under section 20 of the 1989 Children Act. A further $7.5 \%$ were initially detained for child protection under police or emergency protection orders and $42.8 \%$ entered immediately under care proceedings. The higher number of children found in the NFJO report to have been subject to care proceedings within a week of birth suggests that a high proportion of children initially entering care under section 20 had care proceeding initiated in the week after their birth. This would suggest that for these children, along with those detained or entering under emergency protection orders, the placement in care was unplanned. 
Graph 2: Initial Legal order on entry to care of children BIC

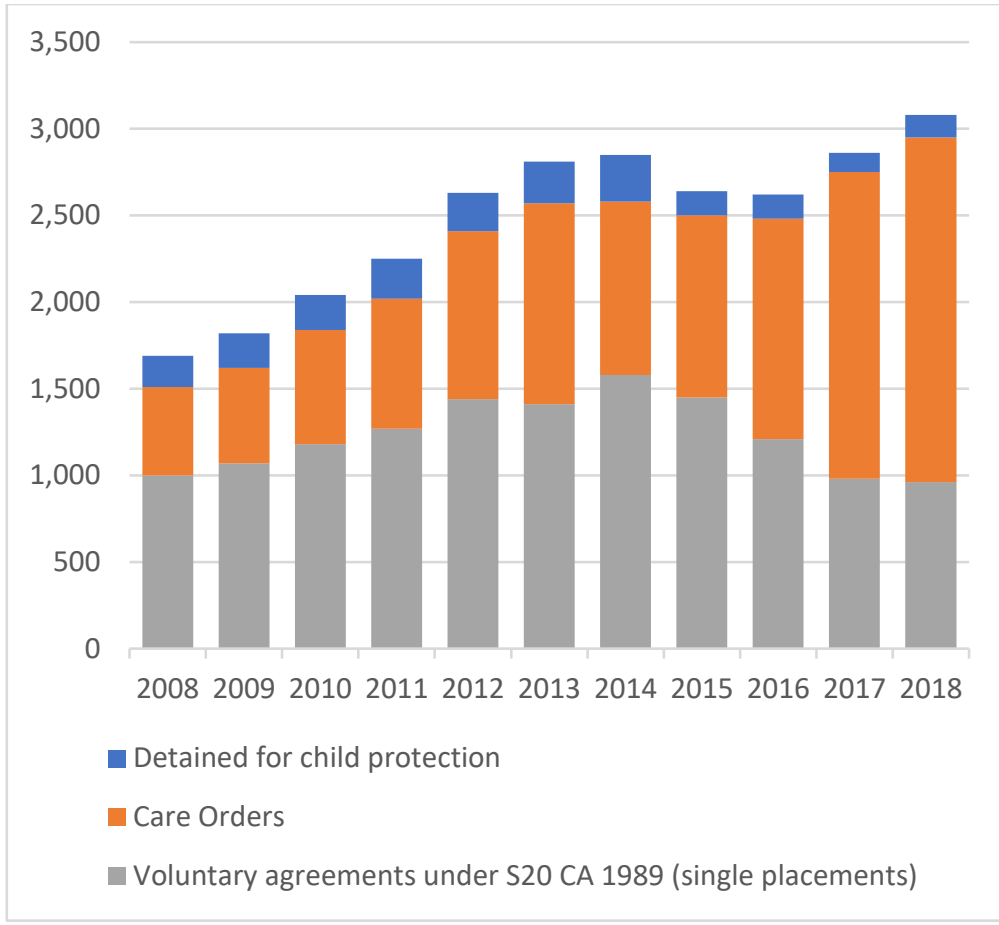

From 2007-8 to 2013-14 all legal routes into care increased (see graph 2). Since then the number of children initially entering care on voluntary agreements has fallen back to the numbers in 2007-8 whilst children entering on care orders has almost quadrupled from 510 to 1990.

Table 1: Children BIC, rate per live births by region, 2017/18

2007-8

2017-18

\begin{tabular}{|c|c|c|c|c|c|}
\hline & Number & Rate/10,000 & Number & Rate/10,000 & $\begin{array}{l}\text { Change in } \\
\text { rate } / 10,000\end{array}$ \\
\hline England & 1,700 & 26 & 3,080 & 48 & +23 \\
\hline East Midlands & 140 & 26 & 270 & 52 & +26 \\
\hline East of England & 140 & 19 & 300 & 42 & +23 \\
\hline Inner London & 140 & 28 & 130 & 27 & -1 \\
\hline North East & 120 & 42 & 280 & 102 & +60 \\
\hline North West & 290 & 34 & 520 & 62 & +28 \\
\hline Outer London & 110 & 14 & 180 & 23 & +9 \\
\hline South East & 210 & 21 & 340 & 34 & +14 \\
\hline South West & 130 & 23 & 270 & 48 & +26 \\
\hline West Midlands & 200 & 28 & 370 & 53 & +25 \\
\hline $\begin{array}{r}\text { Yorkshire and The } \\
\text { Humber }\end{array}$ & 210 & 33 & 410 & 66 & +33 \\
\hline
\end{tabular}

\subsection{Rapid increase in children BIC}

The rate of growth in early admission to care is striking. In the ten-year period from $2007 / 8$ to 2017/18 the rate of children entering care at birth almost doubled from 26 to 48 per 10,000 live births. In other words, the rate increased from one baby in every 386 live births in 2007-8 to one in 
210 in 2017-8. This rise has been continuous over the ten-year period except for two years following the Re B-S case which is discussed further below.

The rate of increase of children $\mathrm{BIC}$ varied considerably by region and local authority. Whilst across England there was an 85.8\% increase in the rate of children BIC between 2007/08 and 2017/18 there were considerable differences across the country. The North East not only had the largest proportion of children BIC in 2017/18, this region also had the largest rate of growth: a 142\% increase (table 1). In contrast, the Inner London region stands out with a slight fall in the rate of children BIC.

There was a small correlation between the increases in the rate of children BIC and the deprivation score of the local authority (Pearson 0.29) and those with higher deprivation score in 2017 had a raised chance of having had larger increases in the rate of children BIC.

Local authority children's social care departments in England have their performance graded from outstanding to inadequate by the Office for Standards in Education (OFSTED). It can be seen from table 2 that, whilst there was little difference in the rates of children BIC in 2007, those departments whose most recent grade was outstanding had the smallest increase in the rate of children BIC. This was slightly smaller than those rated good. However, those rated as requiring improvement or inadequate had a far bigger increase in the $\mathrm{BIC}$ rate.

Table 2: Ofsted grade versus change in the rate of children BIC /10,000 live births

\begin{tabular}{r|rrrr} 
OFSTED Grade & $\begin{array}{l}\text { Number of Local } \\
\text { Authorities }\end{array}$ & $\begin{array}{l}\text { BIC rate } \\
2007\end{array}$ & $\begin{array}{l}\text { BIC Rate } \\
2017\end{array}$ & \multicolumn{2}{c}{$\begin{array}{l}\text { Change in BIC } \\
\text { rate }\end{array}$} \\
\hline Outstanding & 8 & 24.2 & 37.7 & $\mathbf{1 3 . 6}$ \\
Good & 59 & 24.9 & 41.5 & $\mathbf{1 6 . 6}$ \\
Requires improvement & 58 & 28.1 & 53.2 & $\mathbf{2 5 . 1}$ \\
Inadequate & 20 & 23.7 & 51.0 & $\mathbf{2 7 . 3}$
\end{tabular}

We are unable to confirm the causal factors influencing local authority variations from this data but expenditure relative to need (Webb and Bywaters, 2018; Hood et al, 2016) and local culture (Platt and Turney, 2012; Featherstone et al, 2014; Lawler and Bilson, 2009) are two key factors. The ethos of local courts may be another (Masson 2012). In the case of BIC rates we see some evidence which we discuss below, that some local authorities are more likely to favour placing children in alternative homes to their birth families than others and this is reflected not only in BIC rates but care, adoption and special guardianship rates generally. So the systematic inequity in rates is likely to reflect both family socio-economic and demographic circumstances, and local authority expenditure relative to need, culture and performance.

\subsection{Long-term placement outcomes for children BIC}

Most children BIC (87.2\%) between 2007-8 and 2016-17 ${ }^{1}$ were placed in adoption (54.1\%), on a placement order (0.5\%) or placed with special guardians (33.5\%) by the $31^{\text {st }}$ March 2018 (graph 3).

The NFJO study (2018) in England found that $54.1 \%$ of children BIC had placement orders or adoption orders as the final legal outcome and $24.3 \%$ a residence or special guardianship order over their eight year study period if children whose final order was for supervision are excluded. The proportion ending in adoption $(52.7 \%)$ was similar for children entering care in the same period in

\footnotetext{
${ }^{1}$ 2017-18 entrants are excluded as they will not have had time for permanence procedures to have been initiated or completed
} 
this study whilst special guardianship (34.5\%) was lower than in this study. It thus seems that children entering care through 'voluntary' orders were just as likely to be adopted as those entering through care proceedings (see also Lynch, 2017 who found a large proportion of voluntary entries to care were placed in foster to adopt placements). They also appear more likely to be placed in special guardianship.

Thus, the vast majority of children BIC will never return to their parents. Entry to care in week one is rarely to enable an overwhelmed parent to have time and support to get back on their feet.

\subsection{A third of all adopted children BIC}

The graph also shows that there was a fall in the number of children BIC going on to be placed in adoption from its highest level in 2013-14. This was balanced by an increase in the numbers placed in special guardianship (graph 3). This is in line with the overall fall in the number of adoptions in this period which followed judicial rulings in the case of Re B-S (MacFarlane, 2017) which stressed that adoption should be a last resort and that all alternative options should be considered.

Graph 3: Percent of children who left care to under special guardianship or adoption or were on a placement order at by $31^{\text {st }}$ March 2018 by year BIC.

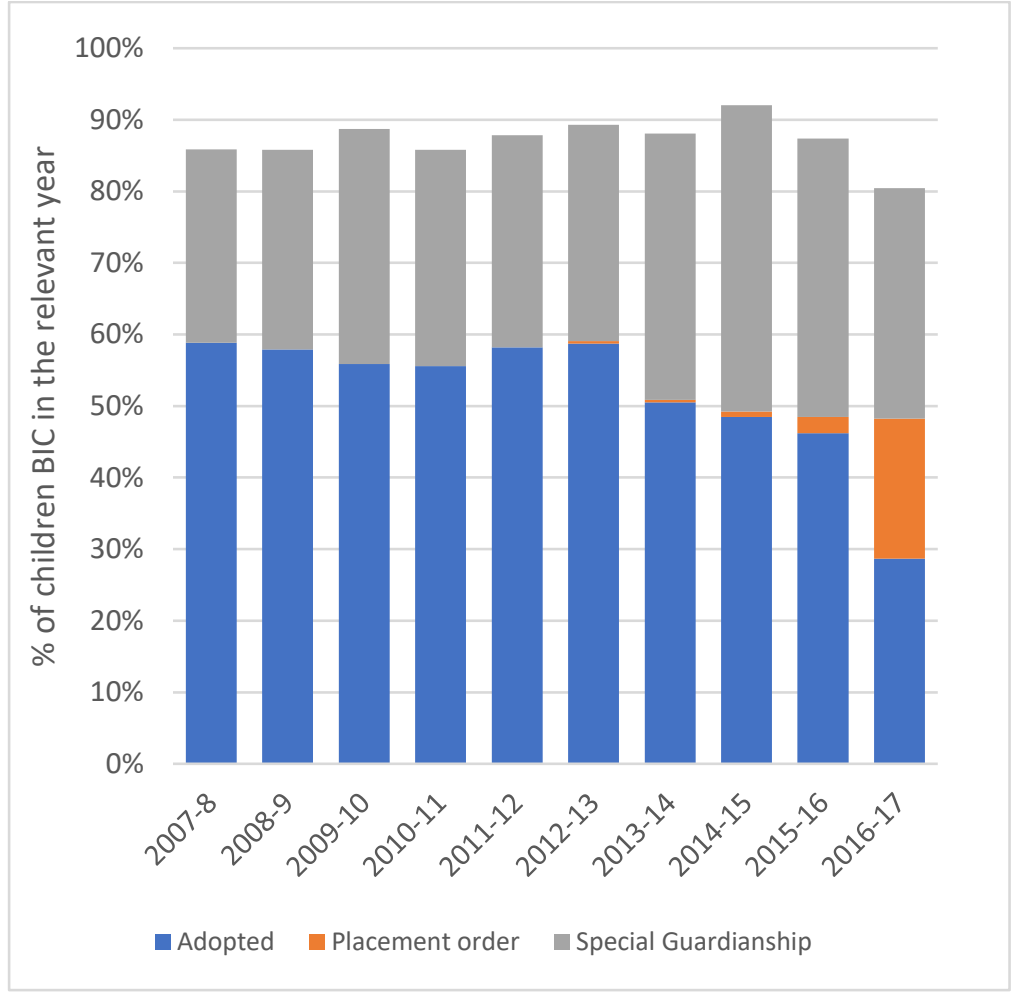

Few children aged 4 and over on entry to care were adopted and a third of all children adopted (32.7\%) from care had been BIC (table 3). The proportion of all children adopted who were BIC rose from $29.2 \%$ in $2007-8$ to a peak of $35.4 \%$ of children adopted in 2013-14 falling back slightly thereafter. The number of adopted children who were BIC increased more than any other age group and the numbers more than doubled (increase of 102.2\%) between 2007-08 and the peak of 201415 whilst other age groups increased by half (54.7\%). Thus the increase in children BIC who went on 
to be adopted was responsible for just over half of the increase of total adoptions between 2007-8 and 2014-15.

Table 3 Age of children on entry to care of those adopted by year of adoption

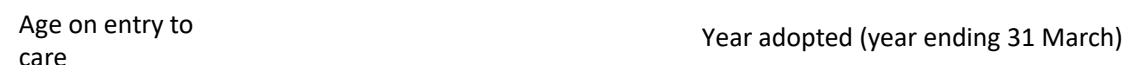

\begin{tabular}{rrrrrrrrrrr}
\hline $\begin{array}{c}2007- \\
08\end{array}$ & \multicolumn{1}{c}{$\begin{array}{c}2008- \\
09\end{array}$} & $\begin{array}{c}2010- \\
11\end{array}$ & $\begin{array}{c}2011- \\
12\end{array}$ & $\begin{array}{c}2011- \\
12\end{array}$ & $\begin{array}{c}2012- \\
13\end{array}$ & $\begin{array}{c}2013- \\
14\end{array}$ & $\begin{array}{c}2014- \\
15\end{array}$ & $\begin{array}{c}2015- \\
16\end{array}$ & $\begin{array}{c}2016- \\
17\end{array}$ & $\begin{array}{c}2017- \\
18\end{array}$ \\
$\mathbf{3 , 1 8 0}$ & $\mathbf{3 , 3 3 0}$ & $\mathbf{3 , 2 0 0}$ & $\mathbf{3 , 1 0 0}$ & $\mathbf{3 , 4 7 0}$ & $\mathbf{4 , 0 1 0}$ & $\mathbf{5 , 0 5 0}$ & $\mathbf{5 , 3 6 0}$ & $\mathbf{4 , 7 1 0}$ & $\mathbf{4 , 3 7 0}$ & $\mathbf{3 , 8 2 0}$ \\
1,950 & 2,070 & 1,980 & 1,940 & 2,250 & 2,610 & 3,340 & 3,490 & 2,880 & 2,620 & 2,300 \\
930 & 980 & 980 & 960 & 1,100 & 1,370 & 1,790 & 1,880 & 1,550 & 1,410 & 1,330 \\
310 & 350 & 290 & 290 & 340 & 340 & 430 & 460 & 390 & 340 & 250 \\
290 & 280 & 290 & 270 & 320 & 340 & 440 & 420 & 320 & 330 & 260 \\
190 & 200 & 190 & 180 & 200 & 250 & 320 & 300 & 250 & 230 & 180 \\
130 & 140 & 140 & 120 & 160 & 170 & 190 & 220 & 180 & 170 & 140 \\
100 & 120 & 100 & 120 & 130 & 160 & 180 & 210 & 190 & 160 & 140 \\
380 & 410 & 360 & 360 & 430 & 490 & 610 & 690 & 630 & 510 & 470 \\
300 & 330 & 300 & 280 & 310 & 370 & 480 & 530 & 470 & 450 & 390 \\
200 & 230 & 240 & 230 & 220 & 260 & 290 & 310 & 340 & 360 & 270 \\
350 & 300 & 330 & 290 & 260 & 280 & 330 & 350 & 400 & 430 & 390 \\
$1: 4$ & $1: 3$ & $1: 4$ & $1: 3$ & $1: 2$ & $1: 1$ & $1: 1$ & $1: 1$ & $1: 3$ & $1: 4$ & $1: 4$
\end{tabular}

mths)

Source: FOI

\subsection{Inequity: between local authorities and between regions}

The NFJO reports drew attention to large differences between regions and between local authorities in a parent's chances of having her or his child taken into care at birth. Our updated data, including all such children, confirms this picture. The rate of babies BIC in 2017-8 across England averaged 48 in every 10,000 live births. This rate varied from none in Rutland and City of London (which have low child populations) to 219 / 10,000 in Blackpool. This means that in Blackpool in 2017-8, one baby in every 46 live births was BIC, an extraordinary proportion.

The chance of being BIC in Blackpool is exceptional, but in 10 LAs the rate was greater than 1 in 100 live births and the average for the 25 local authorities with the highest rates was one baby in 101 live births. By comparison, in the 25 local authorities with the lowest rates a child's chance of being BIC averaged 1 in 542, more than five times lower.

There is also a substantial regional variation in the proportion of babies BIC. As Table 1 shows, around 1 child in 400 in Inner and Outer London were BIC compared to 1 in 100 in the North East. These regional patterns mask large differences between individual local authorities. For example, in the North East region rates varied between 1 in 59 (Hartlepool) and 1 in 223 (North Tyneside).

\subsection{Variations or Inequalities between areas?}

There is a clear relationship between the proportion of children BIC in 2017 and local authority deprivation (Pearson 0.54). Children born into high deprivation local authorities had a greater chance of entering care in their first week than children born in less deprived authorities and on 
average each step down makes a difference. This is to be expected from other studies of the relationship between deprivation and looked after children rates (Bywaters et al., 2018; Hood et al, 2016; Mornington, and Guyard-Nedelec, 2019).

Table 4: Local Authority BIC Rates per 10,000 children (Group1 = highest rates) and Deprivation Scores

\begin{tabular}{lccc} 
Rank of rate BIC & Rate BIC & \\
2017 & $2017-18$ & \multicolumn{1}{l}{ Ave IMD } \\
& & $/ 10,000$ & 2017 \\
& Group 1 & 96.8 & 30.3 \\
Group 2 & 62.6 & 24.4 \\
Group 3 & 47.4 & 22.5 \\
Group 4 & 31.0 & 20.3 \\
Group 5 & 17.1 & 17.5
\end{tabular}

As would be expected from other studies of the care system (Bywaters et al., 2018), there is also a clear social gradient related to the unweighted average deprivation scores of local authorities. If the $\mathrm{BIC}$ rate is divided into 5 groups of 29 or 30 local authorities in which LAs in group 1 have the highest BIC rates - an average rate of 96.8 / 10,000 live births or 1 child BIC per 103 live births - and group 5 the lowest rates - an average rate of 17.1 / 10,000 live births or 1 child BIC per 586 live births (Table 4), the gradient is apparent. Each increase in average rates is accompanied by an increase in average deprivation scores.

However, within each of the five groups there are large differences in LA deprivation scores. For example, in group 1 IMD scores vary from 21 to 45 , and in group 5 from 8 to 29 . This suggests that as would be expected - intervention rates result from a combination of demand and supply factors (Bywaters et al., 2015; Web and Bywaters, 2018; Hood et al, 2016).

\subsection{Variations or Inequalities between children?}

As usual for studies of the UK child protection systems we do not have access to demographic or socio-economic data about the parents of children BIC or households from which they come, because these data are not collected by the national authorities. In this case we also have no individual level data about the children, only data at the local authority level and above. This means that we are unable to examine the social gradient that will undoubtedly exist for individual children.

A comparison of the findings on the ethnicity of children BIC with the population estimates for the number of children aged 0 in mid 2018 (statistics for the ethnicity of live births were not available) showed that mixed ethnicity children were over-represented in the children BIC, black children were somewhat under-represented and Asian children substantially under-represented (Table 5). This also reflects other recent studies of the English child protection system (Bywaters et al., 2019), although evidence to explain these patterns is lacking. Given that Black and Asian families are much more likely than White British families to be living in poverty, these ethnic inequalities are likely to be larger even than they seem if children in similar circumstances were compared. 
Table 5: Percentage of children by ethnic category for those aged 0 in mid 2018 and BIC in 2017-8

\begin{tabular}{|c|c|c|}
\hline & $\begin{array}{c}\text { Children aged } 0 \text { mid } \\
2018 \text { England }\end{array}$ & $\begin{array}{c}\% \text { by ethnicity BIC } \\
2017-8\end{array}$ \\
\hline White British & $70.3 \%$ & $72.1 \%$ \\
\hline White Other & $5.8 \%$ & $3.8 \%$ \\
\hline Mixed & $6.7 \%$ & $11.0 \%$ \\
\hline Asian & $10.5 \%$ & $1.9 \%$ \\
\hline Black & $5.8 \%$ & $3.2 \%$ \\
\hline Other ethnic groups & $0.7 \%$ & $1.3 \%$ \\
\hline $\begin{array}{l}\text { Other including not } \\
\text { known and refused }\end{array}$ & & $6.8 \%$ \\
\hline
\end{tabular}

\subsection{Increasing inequalities between local authorities in BIC rates}

Table 6 shows how these rankings from highest (group 1) to lowest (group 5) rates of children BIC relate to other trends in children's social care. When 2017 rates of children BIC are compared to those in 2007 the difference between these groups has grown significantly. In 2007 the rate in Group 1 was 2.4 times that in Group 5. By 2017 the Group 1 rate was 5.7 times that in Group 5. The rate of children BIC in group 1 had risen by $143 \%$ whilst it was effectively unchanged in group 5 .

\begin{tabular}{|c|c|c|c|c|c|c|}
\hline $\begin{array}{l}\text { Rank of } \\
\text { rate BIC }\end{array}$ & $\begin{array}{l}\text { BIC } \\
\text { rate* }\end{array}$ & $\begin{array}{l}\text { BIC } \\
\text { Rate }^{*}\end{array}$ & $\begin{array}{l}\text { Rate }^{\dagger} \\
\text { care }\end{array}$ & $\begin{array}{l}\text { Rate }^{+} \\
\text {care }\end{array}$ & $\begin{array}{l}\text { Rate }^{+} \text {in } \\
\text { care on }\end{array}$ & $\begin{array}{l}\text { Rate }^{+} \text {in } \\
\text { care on }\end{array}$ \\
\hline 2017 & 2017 & 2007 & $\begin{array}{l}\text { entries } \\
\text { not } B I C\end{array}$ & $\begin{array}{l}\text { entries } \\
\text { not } B I C\end{array}$ & 31.3.17 & 31.3.07 \\
\hline
\end{tabular}

\begin{tabular}{l|llllll}
\hline Group 1 & 96.8 & 39.9 & 34.2 & 21.3 & 95.1 & 63.5 \\
Group 2 & 62.6 & 32.0 & 25.6 & 19.1 & 76.1 & 59.4 \\
Group 3 & 47.4 & 25.7 & 24.2 & 20.2 & 64.2 & 53.9 \\
Group 4 & 31.0 & 20.4 & 22.2 & 19.1 & 53.4 & 50.4 \\
Group 5 & 17.1 & 16.9 & 19.0 & 16.7 & 39.2 & 43.2
\end{tabular}

* Rate per 10,000 live births

${ }^{\dagger}$ Rate per 10,000 aged $0-17$ years data source is DfE 2020

Group 1 has highest rate of children BIC in 2017 and Group 5 has lowest rate

Table is limited to 147 local authorities which existed in both 2007 and 2017

\subsection{Child Rescue or Early Intervention?}

A key justification of the philosophy behind early intervention and the placement of children away from their birth parents in permanent alternative families is to identify children early who would otherwise be harmed more and enter care as older children. If this was the case, then we would expect to see that local authorities with high and increasing rates of children BIC over this 10 year period would have reducing rates of children entering care as older children. Also, because making speedy decisions should increase the possibility of placement for adoption and special guardianship, we would expect lower numbers in care. However, table 6 shows that the reverse is the case: local authorities with high and increasing BIC rates also had high and increasing rates for later intervention. This finding mirrors research on adoption which shows that in England local authorities with the highest rates of adoption from care also had the biggest increases in the care population (Bilson, 2017) as well as increases in other child care interventions including child protection 
investigations (Bilson and Munro, 2019). It is clear that having high rates of children BIC is part of an increasing trend of child removal in authorities with high rates.

Blackpool with the highest rate of children BIC has also been consistently the local authority with the highest rates of children looked after and children adopted from care in the past decade (DFE 2020).

Removing children at birth at an exceptionally high rate has not reduced later high cost and coercive interventions. Rather the reverse. However, Knowsley, the second most deprived local authority after Blackpool and also in the North West region, had consistently lower rates on the same measures (DfE 2020).

Whilst rates of children born into care are strongly associated with rates of deprivation in local authorities other factors are also in play. This is likely to include the availability of support services for parents. The local authorities with large increases in BIC are also more likely to be under scrutiny from Ofsted as shown in section 3.2 with pressure to conform to government policy.

\subsection{A Spiral of failure?}

As we have shown, the group of local authorities that had the highest rates of BIC in 2017 had rapid increases and higher rates of children in care. Parents who themselves were looked after are substantially over-represented in repeat entries to care (Broadhurst et al 2017). Care leavers' children are also highly likely to enter care (Roberts, Maxwell and Elliott, 2019; Dixon et al, 2006) and then to be adopted (Roberts et al, 2017; Roberts et al, 2019). The parents of half of children BIC have had a previous child removed and many of those for whom it is the first time will experience further removals. Thus a considerable majority of these parents will be subject of recurrent proceedings. Broadhurst et al's study (2017) of recurrent care proceedings found that $40 \%$ had themselves been in care. The correlation of high rates of children BIC with high and increasing rates of children in care may thus indicate a spiral of failure as parents who have been in care lose their own children to the care system.

\section{Conclusion}

The extent to which children are being taken into care at birth in England is shown here to be significantly greater even than the rates previously reported. In 25 local authorities an average of one child in every 100 live births is separated from its parents in the first week in life, with very few ever being reunited. In one local authority this rises to one child in every 46 . Half of all parents who lose their children in the first week of life have never previously had a child removed. Their capacity to parent is judged by prediction not past performance. Many parents who have previously lost a child will have had little or no subsequent help to come to terms with their loss, or to deal with other problems. We consider it to be a scandal that one of the richest nations in the world cannot better prepare, resource and support parents for that most important and valued of life tasks: looking after your children.

While local authority deprivation levels are shown to correlate with high $\mathrm{BIC}$ rates, there are other factors including poor local authority performance which mean that children in some places are significantly more likely to end up in care than children in similar circumstances in other places with similar resources. More research is needed but the link between high rates of BIC and high and increasing rates of children in care may indicate a spiral of failure as high proportions of parents who have been in care lose their own children at birth.

The English approach to adoption - both the scale of adoption and the willingness to dispense with parental consent - is an outlier amongst European countries (Fenton Glynn, 2015). The promotion of permanent alternative placements (whether through adoption or special guardianship) has been a 
key feature of English child protection policy in the past decade and more, with some leading politicians taking a particularly pro-adoption position and, at times, finding themselves at odds with leading members of the Family Court. The combination of cuts in preventive services (Clements et al, 2017), increasing inequality (Bywaters et al, 2018), the government's promotion of child rescue (Parton and Williams, 2017) and the huge increase in child protection investigations (Bilson and Munro,2019) has created a hostile environment for parenting. This study suggests that the growth in numbers and proportions of children entering care in the first week of life is a key driver of adoption rates. But far from acting as a form of prevention, with lower proportions of older children in care where local authorities have high rates of very early removal from birth parents, the opposite is true. Local authorities who have high rates of early early separation also tend to prioritise the use of care throughout childhood. This suggests that there remains a powerful contest nationally and between local authorities over whether child rescue or family support is the preferred policy objective.

This ambivalence about supporting birth families has both human and financial consequences. While many adoptions are considered successful, they are almost never without complications or heartache which follow both children and parents throughout their lives (Featherstone et al., 2018). Following a decade of austerity policies almost half the entire children's social care budget is now spent on children in care.

While data about individual parents is lacking parents' financial and material circumstances will make a profound difference to their chances of losing a child through state action in the first week in life. It is clear that most children who are adopted will be moving to a home which can command more - and more secure - material resources. Being BIC is an acute example of the underlying structural inequalities that are a feature of children's social care in England. 


\section{References}

1. Allen, G. (2011) Early Intervention: The Next Steps.

https://assets.publishing.service.gov.uk/government/uploads/system/uploads/attachment data/file/284086/early-intervention-next-steps2.pdf

2. Bellew R and Peeran U (2017) After Adoption's Breaking the Cycle programme: An evaluation of the two year pilot, September 2014 to August 2016. London: Coram

3. Bilson A., Munro E.H., (2019) Adoption and Child Protection Trends for children aged under five in England: Increasing investigations and hidden separation of children from their parents, Children and Youth Services Review 96:204-211

4. Bilson A., (2017) The government's adoption drive isn't achieving its aims. Community Care February $9^{\text {th }}$ https://www.communitycare.co.uk/2017/02/09/the-governmentsadoption-drive-isnt-doing-what-it-set-out-to-do/

5. Broadhurst, K., Alrouh, B., Yeend, E., Harwin, J., Shaw, M., Pilling, M., Mason, C. and Kershaw, S. (2015) Connnecting Events in Time to Identify a Hidden Population: Birth Mothers and Their Children in Recurrent Care Proceedings in England. British Journal of Social Work (November):1-20. https://doi:10.1093/bjsw/bcv130

6. Broadhurst, K. and Mason, C. (2017) 'Birth parents \& the collateral consequences of courtordered child removal: Towards a comprehensive framework', International Journal of Law, Policy and the Family, 31(1): 41-59. https://doi:10.1093/lawfam/ebw013

7. Broadhurst, K., Mason, M.C., Bedston, S., Alrouh, B., Morriss, L., McQuarrie, M.T., Palmer, M., Shaw, M., Harwin, J. and Kershaw, M.S., 2017. Vulnerable birth mothers and recurrent care proceedings. Lancaster: University of Lancaster.

https://www.nuffieldfoundation.org/wp-content/uploads/2017/10/rc-final-summaryreport-v1 6.pdf

8. Brown, R., \& Ward, H. (2012). Decision-making within a child's timeframe: An overview of current research evidence for family justice professionals concerning child development and the impact of maltreatment. London, Childhood Wellbeing Research Centre.

http://www.adoptionplus.co.uk/userassets/docs/Decisionmaking within a child $s$ timeframe.pdf

9. Bywaters, P., Brady, G., Sparks, T., Bos, E., Bunting, L., Daniel, B., Featherstone, B., Morris, K. \& Scourfield, J., (2015) Exploring inequities in child welfare and child protection services: explaining the 'inverse intervention law', Children and Youth Services Review 57, October: 98-105. https://www.sciencedirect.com/science/article/pii/S0190740915300256

10. Bywaters, P., Brady, G., Bunting, L., Daniel, B., Featherstone, B., Jones, C., Morris, K, Scourfield, J., Sparks, T., Webb, C. (2018) Inequalities in English child protection practice under austerity: a universal challenge? Child and Family Social Work 23 (1): 53-61. https://doi.org/10.1111/cfs.12383

11. Bywaters, P., Scourfield, J., Webb, C., Morris, K., Featherstone, B., Brady, G. Jones, C. and Sparks, T. (2019) Paradoxical evidence on ethnic inequities in child welfare: towards a research agenda. Child and Youth Services Review 96: 145-154.

https://doi.org/10.1016/j.childyouth.2018.11.042

12. Clements, K., Ellison, R., Hutchinson, D., Moss, D., \& Renton, Z. (2017). No Good Options: Report of the Inquiry into Children's Social Care in England. London: All Party Parliamentary Group on Children. Retrieved from https://www.ncb.org.uk/sites/default/files/field/attachment/No\%20Good\%200ptions\%20R eport\%20final.pdf.

13. Cox P, Barratt C, Blumenfeld F, Rahemtulla Z, Taggart D and Turton J (2015) Reducing Recurrent Care Proceedings: Service Evaluation of Positive Choices (Suffolk County 
Council) and Mpower (Ormiston Families). Unpublished report, University of Essex.

Available online: http://www.essex.ac.uk/-/media/documents/research/recurrent-careproceedings.pdf

14. Department for Education (2020) Statistics on children under local authority care at national and local authority level. https://www.gov.uk/government/collections/statisticslooked-after-children

15. Featherstone, B., Gupta, A. and Mills, S. (2018) The role of the social worker in adoption ethics and human rights: An Enquiry. BASW.

https://www.basw.co.uk/system/files/resources/basw 55505-10 1.pdf

16. Featherstone, B., Morris, K., \& White, S. (2014). Re-imagining child protection: Towards humane social work with families. Bristol, Policy Press.

17. Fenton-Glynn, C. (2015) 'Adoption without consent', 1. doi: 10.1017/СВO9781107415324.004.

18. Field, F. (2010) The Foundation Years: preventing poor children becoming poor adults. https://webarchive.nationalarchives.gov.uk/20110120090141/http://povertyreview.indepe ndent.gov.uk/media/20254/poverty-report.pdf

19. Harwin, J., Alrouh, B., Palmer, M., Broadhurst, K. and Swift, S. (2016) 'Considering the case for parity in policy and practice between adoption and special guardianship: findings from a population wide study', Family law, 46(2), pp. 204-207.

20. Hood, R., Goldacre, A., Grant, R., \& Jones, R. (2016). Exploring demand and provision in English child protection services. The British Journal of Social Work, 46(4), 923-941.

21. HM Government (2013) Working Together to Safeguard Children: A guide to inter-agency working to safeguard and promote the welfare of children. London, HM Government

22. Lawler, J., \& Bilson, A. (2009). Social work management and leadership: Managing complexity with creativity. Abingdon, Routledge.

23. Lynch, C. (2017) Cooperation or coercion?: Children coming into the care system under s 20 voluntary arrangements. London, Family Rights Group. https://www.frg.org.uk/images/YFYV/KI-Report-10.07-final.pdf

24. Masson, J. (2012). What are care proceedings really like?. Adoption \& Fostering, 36(1), 5-12.

25. McFarlane, A, (2017) Holding the risk: The balance between child protection and the right to family life, Family Law 47, 6, 610-24.

26. McFarlane, A, (2018) Speech at Care Crisis Review launch. Family Law https://www.familylaw.co.uk/news and comment/sir-andrew-mcfarlane-delivers-speechat-care-crisis-review-launch

27. McGrath-Lone, L., Harron, K., Dearden, L., \& Gilbert, R. (2018). Exploring longitudinal care histories for looked after children: a sequence analysis of administrative social care data. International Journal of Population Data Science, 3(2).

28. Mornington, A. D., \& Guyard-Nedelec, A. (2019). Is poverty eroding parental rights in Britain? The case of child protection in the early twenty-first century. In Philosophy and Child Poverty (pp. 341-361). Springer, Cham.

29. Nuffield Family Justice Observatory for England \& Wales (2018) BIC Newborns in care proceedings in England. London: Nuffield Foundation.

https://www.nuffieldfjo.org.uk/app/nuffield/filesmodule/local/documents/Born\%20into\%20Care Final\%20Report 10\%200ct\%202018.pdf

30. Nuffield Family Justice Observatory for England and Wales (2019) BIC: newborns and infants in care proceedings in Wales. London: Nuffield Foundation.

https://www.nuffieldfjo.org.uk/app/nuffield/filesmodule/local/documents/Born\%20into\%20care\%20Wales\%20\%20main\%20report English final web.pdf 
31. Parton, N., \& Williams, S. (2017). The contemporary refocusing of children's services in England. Journal of Children's Services.

32. Platt, D., \& Turney, D. (2012). Thresholds for child protective interventions: a conceptual analysis. British Journal of Social Work, 43(2), 1-19.

33. Roberts, L., Meakings, S., Forrester, D., Smith, A., \& Shelton, K. (2017). Care-leavers and their children placed for adoption. Children and Youth Services Review, 79, 355-361.

34. Roberts, L., Maxwell, N., \& Elliott, M. (2019). When young people in and leaving state care become parents: What happens and why? Children and Youth Services Review, 104, 104387.

35. Wastell, D., \& White, S. (2012). Blinded by neuroscience: Social policy, the family and the infant brain. Families, Relationships and Societies, 1(3), 397-414.

36. Wastell, D., \& White, S. (2017). Blinded by science: The social implications of epigenetics and neuroscience. Bristol, Policy Press.

37. White, S., Gibson, M., \& Wastell, D. (2019). Child protection and disorganized attachment: A critical commentary. Children and Youth Services Review, 105, 104415.

38. Webb CJR, Bywaters P. (2018) Austerity, rationing and inequity: trends in children's and young peoples' services expenditure in England between 2010 and 2015. Local Government Studies https://doi.org/10.1080/03003930.2018.1430028 